\title{
Dignity at Work: Why it Matters
}

Throughout the history of social science, dignity is a word that is continually used to express concern about various aspects of work. Within these concerns we see a set of implicit understandings of what dignity is, and what it does, and profoundly, dignity as an essential need of the human spirit. Beginning with some of the earliest insights that inform contemporary analyses of work we can see that, in different ways and relating their concerns to different eras, writers on work and organisation each conceptualise increasing industrialisation as entailing a possible denial of dignity.

Most recently the dignity at work debate been colonised by the focus on bullying and harassment. The high profile campaign for 'dignity at work' (cf: Amicus and The Andrea Adams Trust) draws attention to the everyday bullying behaviours that occur in the workplace serving to intimidate and oppress employees, coming both from the workplace hierarchy, and, whether through cultural consensus or individual mal-intent, from peers. This reflects a feeling that some fundamental rights are coming under pressure. The proposed UK 'dignity at work act' advises that 'every employee shall have the right to dignity at work’.

Linked to the focus on bullying there have been varied calls for building cultures of respect where some of the core concerns of this campaign are clearly related to substantive structural matters not dissimilar to earlier concerns relating to autonomy and worth. Nevertheless, the campaign for 'dignity at work' focuses very much on indignities caused by intimidation from over-zealous managers or competitive colleagues and tends to miss that dignity at work is related to a wide range of issues not always linked to bullying.

At a broader level there are valuable critiques of contemporary work that highlight the inequalities in access to well-paid work and safe and secure working conditions along with the role of 'mis-management'; all specific tangibles of the achievement of dignity at work. Contemporary critical accounts of work and a related focus on potential denials of dignity offer a balance to the hyperbole of the Knowledge Economy rhetoric and question what the realities (and potential indignities) of work are for the majority of people. Whilst recognising that 'bad' work or 'mis-management' is unlikely to disappear there is a call to ensure that policy makers and companies recognise what the ingredients of good work might be - a recipe that clearly reflects the International Labour Organisation's (ILO) definition of 'decent work' in its emphasis on equality of access, employee voice and just reward. Given the focus on 'good work', and the growing concerns regarding its lack, an examination of work in the knowledge economy through the holistic lens of dignity at work seems timely.

\author{
Sharon C. Bolton \\ Professor of Organisational Analysis \\ Strathclyde University Business School \\ sharon.bolton@gsb.strath.ac.uk
}




\section{Key Readings:}

Bolton, S. C. (2007) Dimensions of Dignity at Work, London: Butterworth Heineman Coats, D. (2007) 'Respect at Work: Just how Good are British Workplaces?' in Bolton, S. C. (ed.) Dimensions of Dignity at Work, London: Butterworth Heineman Hodson, R. (2001) Dignity at Work. Cambridge: Cambridge University Press.

Hodson, R. (2007) 'The Consequences of Management Competence for Working with Dignity' in Bolton, S. C. (ed.) Dimensions of Dignity at Work, London: Butterworth Heineman.

Rayman, P. (2001) Beyond the Bottom Line, New York: Palgrave.

Sayer, A. (2007) 'What Dignity at Work Means', in Bolton, S. C. (ed.) Dimensions of Dignity at Work, London: Butterworth Heineman.

Sayer, A. (2007) 'Dignity at Work: Broadening the Agenda', Organization, 14, 4: 565 581

\section{References and Useful Reading:}

AMICUS. www.amicustheunion.org

Andrea Adams Trust. www.andreaadamstrust.org

Bunting, M. (2004) Willing Slaves: How the overwork culture is ruling our lives, London: Harper Collins.

Coats, D. (2005a) Ideopolis: Knowledge Cities Working Paper 1: What is the Knowledge Economy? The Work Foundation. http://www.theworkfoundation.com/pdf/Working_paper.pdf

Coats, D (2005b) An agenda for work: The work foundation's challenge to policy makers. Provocation Series, The Work Foundation. 1, 2 . http://www.theworkfoundation.com/pdf/Agenda_for_work.pdf

Dignity at Work Act (2001) http://www.parliament.the-stationeryoffice.co.uk/pa/ld200102/ldbills/031/2002031.pdf

Ehrenreich, B. (2001). Nickel and Dimed: Undercover in Low-Wage USA. London: Granta Books.

Fox, M. (1994) The Reinvention of Work, San Francisco: Harper

Hodson, R. (1996) 'Dignity in the Workplace under Participative Management: Alienation and Freedom Revisited', American Sociological Review, 61, 5, pp.719

Hodson, R. and Roscigno, V. J. (2004) 'Organizational Success and Worker Dignity: Complementary or Contradictory?', American Journal of Sociology, 110, 3, pp. 672 ,

International Labour Organisation (2005) Decent Work: The Heart of Social Progress. http://www.ilo.org/public/english/decent.htm

Lutz, M. A. (1995) 'Centering Social Economics on Human Dignity', Review of Social Economy, Vol LIII, 2: 171-194.

Moynagh, M and Worsley, R. (2005) Working in the twenty-first century, ESRC and the Tomorrow Project

Raynor, C. (2007) 'Preparing for dignity: tackling indignity at work', in Bolton, S. (ed.) Dimensions of Dignity at Work, Oxford: Butterworth Heinemann. 
Sayer, A. (2000) 'Moral Economy and Political Economy', Studies in Political Economy, Spring, pp. 79-103.

Sennett, R. (2003) Respect: The Formation of Character in a World of Inequalities, London: Allen Lane.

Taylor, R. (2002) 'Britain's World of Work-Myths and Realities', Economic and Social Research Council. www.esrctoday.co.uk

Thompson, P. (2005) 'Skating on Thin Ice: The Knowledge Economy Myth' University of Strathclyde.

Toynbee, P. (1975, 2003) 'Hard Work. Life in Low Pay Britain', London: Bloomsbury

United Nations (1948) Universal Declaration of Human Rights. General Assembly of the United Nations.

Wright, L. and Smye, M. (1997) Corporate Abuse, New York: Simon and Schuster 